\title{
PEMBUATAN SISTEM INFORMASI PENGARSIPAN SURAT PADA KANTOR DESA SANDIK BERBASIS WEBSITE
}

\author{
(a Web-Based Mail Filing Information System at the Sandik Village Office)
}

\author{
Ande Rizky Riefnaldi ${ }^{[1]}$, Arik Aranta ${ }^{[1]}$, Muhammad Muaidi $^{[2]}$ \\ ${ }^{[1]}$ Dept Informatics Engineering, Mataram University \\ Jl. Majapahit 62, Mataram, Lombok NTB, INDONESIA \\ ${ }^{[2]}$ Kantor Desa Sandik \\ Jl. Pariwisata, Sandik, Lombok Barat, Lombok NTB, INDONESIA \\ Email: anderizky07@gmail.com, arikaranta@unram.ac.id, affangagah06@gmail.com
}

\begin{abstract}
Abstrak
Di era globalisasi ini perkembangan teknologi dari waktu ke waktu begitu pesat sehingga membuat pekerjaan manusia dipermudah dengan adanya teknologi saat ini, yang pada umumnya akan diselesaikan dengan cepat. Teknologi informasi pada bidang instansi mampu menjadi salah satu media pengetahuan dan pengelolaan informasi manajemen. Kantor Desa Sandik merupakan kantor milik pemerintah daerah yang terletak di Desa Sandik, Lombok Barat, Nusa Tenggara Barat yang melayani masyarakat dalam melakukan semua hal yang berkaitan dengan urusan pemerintahan. Pada Kantor Desa Sandik ini memiliki cukup banyak data dalam hal pengarsipan surat, baik surat masuk maupun surat keluar. Namun pengarsipan surat masih dilakukan secara manual sehingga dalam jangka waktu panjang akan menyebabkan terjadinya penumpukan data arsip yang ada, baik itu surat masuk dan surat keluar. Maka dari itu dibuatlah sebuah sistem informasi pengarsipan surat pada Kantor Desa Sandik. Metode yang digunakan adalah waterfall dengan beberapa tahapan yang runtut dari analisis kebutuhan, desain sistem, coding dan testing, penerapan program, serta pemeliharaan. Pengujian menggunakan user acceptance testing yang di dalamnya terdapat pengujian black box dan kuesioner. Berdasarkan pengujian yang telah dilakukan, maka didapatkan hasil bahwa 5 responden yang mengisi kuisioner yang merupakan pegawai setuju dengan sistem informasi pengarsipan surat yang telah dibuat.
\end{abstract}

Keywords: Perkembangan Teknologi, Sistem Informasi, Arsip Surat, Metode Waterfall, User Acceptance Testing

\section{Pendahuluan}

\subsection{Latar Belakang}

Di era globalisasi ini perkembangan teknologi dari waktu ke waktu begitu pesat sehingga membuat pekerjaan manusia dipermudah dengan adanya teknologi saat ini, yang pada umumnya akan diselesaikan dengan cepat. Teknologi merupakan salah satu alat bantu yang sering digunakan pada aktivitas manusia, yang mana perannya begitu penting seperti halnya dalam mendapatkan suatu informasi dengan cepat ataupun mendata suatu informasi [1]. Dari peran ini, teknologi mampu mengolah suatu data dengan efisien dan terstruktur sehingga dapat bermanfaat bagi pengguna teknologi. Pengolahan data begitu perlu dilakukan pada setiap instansi ataupun organisasi yang mana data yang bernilai informasi mampu meningkatkan produktivitas pekerjaan, waktu dan biaya.

Kantor Desa Sandik merupakan kantor milik pemerintah daerah yang terletak di Desa Sandik, Lombok Barat, Nusa Tenggara Barat yang melayani masyarakat dalam melakukan semua hal yang berkaitan dengan urusan pemerintahan. Kantor Desa Sandik memiliki seorang operator yang mengelola semua data pada kantor tersebut sehingga akan kewalahan dalam pendataannya. Pada Kantor Desa Sandik ini memiliki cukup banyak data dalam hal pengarsipan surat, baik surat masuk maupun surat keluar.

Pengarsipan surat secara manual dalam jangka waktu panjang akan menyebabkan terjadinya penumpukan data arsip yang ada, baik itu surat masuk dan surat keluar. Sehingga dapat menyulitkan dalam mencari suatu data surat yang telah lama. Selain itu, arsip surat juga akan memakan ruang jika terus dilakukan secara manual.

Sistem informasi merupakan suatu sistem yang menyediakan informasi untuk memanajemen dalam mengambil keputusan dan juga untuk menjalankan operasional perusahaan, yang mana sistem tersebut merupakan kombinasi dari manusia, sistem informasi, dan prosedur-prosedur yang terorganisasi [2]. Dengan adanya sistem informasi dapat mempermudah dalam melakukan pendataan atau pengelolaan dari sistem yang akan dibuat nantinya.

Maka dari itu, pada pengabdian kepada masyarakat ini perlu dibuat sebuah sistem informasi pengarsipan surat untuk dapat mempermudah dalam melakukan pengarsipan, pendataan serta pengelolaan berkas-berkas surat 
yang ada serta membuat proses pengarsipan lebih mudah serta lebih efektif, karena operator tidak perlu lagi melakukan pengarsipan surat secara manual.

\subsection{Rumusan Masalah}

Berdasarkan latar belakang yang telah dipaparkan, maka dapat dirumuskan pokok permasalahan yaitu bagaimana cara merancang sistem pengarsipan surat berbasis web yang dapat digunakan untuk mempermudah pengarsipan surat pada Kantor Desa Sandik?

\subsection{Batasan Masalah}

Berdasarkan rumusan masalah yang telah dipaparkan, dapat diambil rumusan masalah adalah sebagai berikut:

1. Sistem informasi pengarsipan surat pada Kantor Desa Sandik merupakan sebuah sistem informasi berbasis web yang dibangun terbatas pada fitur untuk melihat maupun mengelola data pengarsipan surat untuk surat masuk maupun surat keluar, menambahkan data surat masuk maupun surat keluar, dan mengelola data laporan surat masuk maupun surat keluar.

2. Sistem yang dibangun merupakan sebuah sistem informasi yang dapat digunakan oleh operator Kantor Desa Sandik.

3. Sistem informasi yang akan dibuat berbasis web dengan menggunakan Bahasa pemrograman PHP dan MySQL.

\subsection{Tujuan}

Tujuan dari pembuatan sistem informasi pengarsipan surat pada Kantor Desa Sandik ini adalah:

1. Merancang dan membuat sebuah sistem informasi pengarsipan surat berbasis web sebagai sarana pengarsipan surat pada Kantor Desa Sandik.

2. Mempermudah pengarsipan, pengelolaan, dan penyimpanan surat pada Kantor Desa Sandik.

\subsection{Manfaat} berikut:

Manfaat dari pembuatan sistem informasi pengarsipan surat pada Kantor Desa Sandik ini adalah sebagai

1. Bagi Operator

a. Pengarsipan surat dapat lebih terstruktur dan juga lebih hemat kertas jika dibandingkan dengan pengarsipan surat secara manual.

b. Dengan adanya sistem informasi pengarsipan surat pada Kantor Desa Sandik ini, operator akan lebih mudah untuk mengelola pegarsipan surat.

c. Dapat memudahkan operator untuk melakukan pencarian surat-surat yang ada.

2. Bagi Mahasiswa

a. Pada proses pembuatan sistem informasi ini, mahasiswa dapat menerapkan dan dapat menambah pemahaman dalam pembuatan web menggunakan PHP dan MySQL.

b. Menambah pengalaman mahasiswa dalam bekerja pada suatu instansi.

\section{TINJAUAN PUSTAKa}

\subsection{Sistem Informasi}

Sistem informasi adalah kumpulan dari subsistem apapun baik fisik ataupun non-fisik yang saling berhubungan satu sama lain dan bekerja sama secara harmonis untuk mencapai satu tujuan yaitu mengolah data menjadi informasi yang memiliki arti dan berguna [3]. Selain itu sistem informasi adalah suatu sistem di dalam suatu organisasi yang mempertemukan kebutuhan pengolahan transaksi harian, mendukung operasi, bersifat manajerial dan kegiatan strategi dari suatu organisasi dan menyediakan pihak luar tertentu dengan laporan-laporan yang diperlukan [4]. Pengertian lain juga mengatakan bahwa sistem informasi adalah suatu sistem di dalam organisasi yang mempertemukan kebutuhan pengelolaan transaksi harian yang mendukung fungsi organisasi yang manajerial dalam kegiatan srtategi dari suatu organisasi untuk dapat menyediakan pihak luar tertentu dengan laporan-laporan yang di perlukan [5].

\subsection{Basis Data}

Basis data terdiri dari 2 kata, yaitu basis dan data. Basis kurang lebih diartikan sebagai markas atau gudang, tempat bersarang/berkumpul. Sedangkan data adalah representasi fakta dunia nyata yang mewakili suatu objek seperti manusia (pegawai, siswa, pembeli, pelanggan), barang, hewan, peristiwa, konsep, keadaan, dan sebagainya, yang direkam dalam bentuk angka, huruf, simbol, teks, gambar, bunyi/suara, atau kombinasinya [6].

\subsection{Aplikasi Berbasis Web dan Website}

World Wide Web atau yang biasa disebut web, merupakan salah satu sumber daya internet yang berkembang pesat. Teknologi web memanfaatkan bahasa yang disebut HTML (Hyper Text Markup Language) dan protokol 
yang digunakan dinamakan HTTP (Hyper Text Tansfer Protocol). Perkembangan berikutnya, sejumlah skrip dan objek dikembangkan, seperti PHP, ASP, dan applet (Java) [6]. HTML merupakan pemrograman web yang memiliki sintak atau aturan tertentu dalam menuliskan script atau kode-kode, sehingga browser dapat menampilkan informasi dengan membaca kode-kode HTML. HTML adalah sekumpulan simbol-simbol atau tag-tag yang dituliskan dalam sebuah file yang digunakan untuk menampilkan halaman pada web browser [7]. Sedangkan website merupakan sebuah kumpulan halaman-halaman web beserta file-file pendukungnya, seperti file gambar, video, dan file digital lainnya yang disimpan pada sebuah web server yang umumnya dapat diakses melalui internet [8].

\subsection{UML}

Unified Modelling Language (UML) merupakan alat perancangan sistem yang berorientasi pada objek. UML diagram memiliki tujuan utama untuk membantu tim pengembangan proyek berkomunikasi, mengeksplorasi potensi desain, dan memvalidasi desain arsitektur perangkat lunak atau pembuat program [9]. UML adalah bahasa yang menggambarkan cara kerja maupun struktur menggunakan konsep OOP (Object Oriented Programming), sehingga dapat dilihat dari struktur data yang diberikan, tingkah laku apa saja dari suatu objek hingga aktivitas aktivitas yang ada di dalamnya [10].

\subsection{ERD}

ERD (Entity Relationship Diagram) merupakan sebuah diagram yang digunakan untuk merancang hubungan antar tabel-tabel dalam basis data [6]. ERD (Entity Relation Diagram) berguna untuk menggambarkan gambaran dari dunia nyata yang akan diterapkan pada suatu database sebuah sistem. Dengan ERD sendiri dapat membantu mengurangi kesalahan - kesalahan dalam melakukan perancangan database dari gambaran dunia nyata dan struktur database seperti redudansi data, hubungan - hubungan antara entitas, dan lain sebagainya.

\subsection{PHP}

PHP digunakan sebagai bahasa script server-side dalam pengembangan web yang disisipkan pada dokumen HTML. Penggunaan PHP memungkinkan web dapat dibuat dinamis sehingga maintenance situs web tersebut menjadi lebih mudah dan efisien [11].

\subsection{MySQL}

MySQL merupakan DBMS open source (kode programnya dapat di-download gratis) dan freeware (gratis dipakai), walau gratis MySQL tidak bisa dikatakan DBMS kurang baik karena gratis, hal ini terbukti dengan adanya sebuah operator telepon selular yang menggunakan DBMS ini dan memiliki sistem yang andal dengan optomasi. Sampai saat ini MySQL masih menjadi DBMS open source paling banyak digunakan di dunia. MySQL terkenal dengan kecepatan dalam pengaksesan datanya. MySQL saat ini dimiliki oleh perusahaan Oracle [12].

\subsection{Bootstrap}

Bootstrap merupakan framework untuk membangun desain web secara responsif. Artinya, tampilan web yang dibuat oleh bootstrap akan menyesuaikan ukuran layer dan browser yang kita gunakan baik di desktop, tablet ataupun mobile device. Dengan bootstrap kita juga bisa membangun web dinamis ataupun statis [13].

\section{Metode Pengabdian masyarakat}

\subsection{Metode Pengabdian Masyarakat}

Pada kegiatan pengabdian masyarakat di Kantor Desa Sandik ini dilakukan pembuatan sistem informasi pengarsipan surat dimana tahapan yang dilakukan dalam kegiatan pengabdian sebagai berikut:

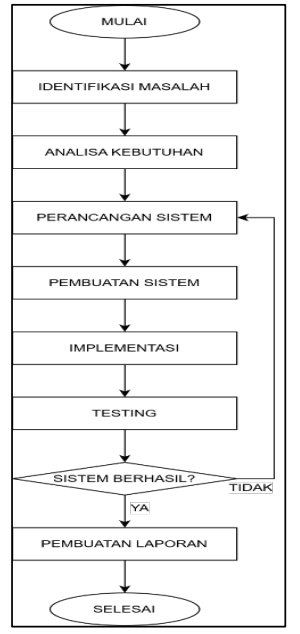

Gambar 1. Flowchart kegiatan pengabdian 
Berdasarkan flowchart pada Gambar 1, proses pembuatan sistem informasi pengarsipan surat dimulai dengan melakukan identifikasi masalah yang ada pada Kantor Desa Sandik dalam hal pengarsipan surat. Setelah melakukan identifikasi masalah, dilanjutkan dengan analisis kebutuhan yang diperlukan dalam pembuatan sistem informasi pengarsipan surat, baik dengan menganalisis metode sebelumnya dengan metode yang akan dibuat. Selanjutnya dilakukan perancangan sistem, seperti menentukan metode yang digunakan, alur dari program, dan sebagainya. Setelah perancangan dilakukan, maka akan dilakukan pembuatan sistem informasi pengarsipan surat. Setelah program selesai dibuat, kemudian dilakukan implementasi dan testing dari sistem yang dibuat. Jika program berhasil, maka akan dilanjutkan dengan pembuatan laporan, namun sebaliknya jika program belum berhasil, maka akan dilakukan perbaikan dimulai dari perancangan sistem, dan akan terus diulang sampai program berhasil dan selesai. Berikut merupakan analisis serta gambaran dari keadaan sistem sebelumnya dan sistem yang akan dibuat:

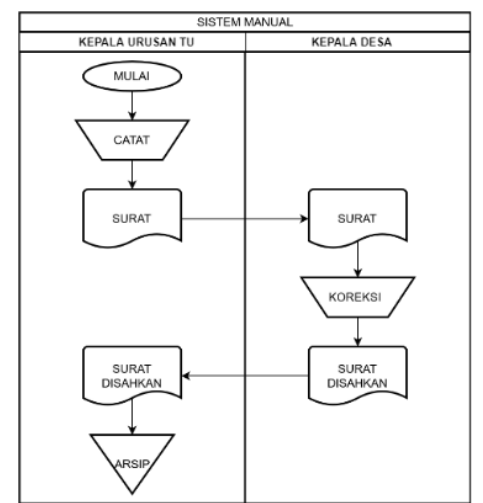

Gambar 2. Sistem pengarsipan surat secara manual

Sistem yang sebelumnya digunakan untuk pengarsipan surat oleh Kantor Desa Sandik adalah menggunakan sistem manual, yang mana sistem ini memiliki banyak kekurangan seperti setiap surat akan dicatat dan diarsipkan secara manual pada suatu tempat atau ruangan untuk mengarsipkan surat, sehingga membutuhkan waktu yang cukup lama untuk melakukan pengarsipan dan pencarian surat.

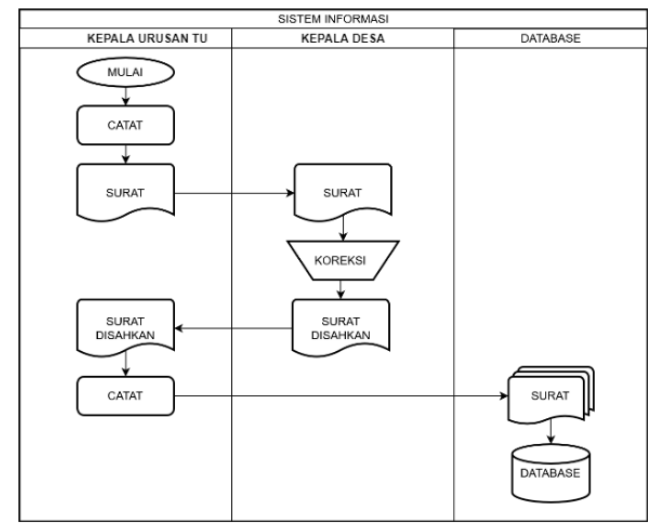

Gambar 3. Sistem pengarsipan surat menggunakan sistem informasi

Sistem pengarsipan surat berbasis web dibutuhkan untuk memudahkan dalam melakukan pengarsipan surat, seperti menghemat ruang serta mempermudah dalam pengelolaan berkas. Data surat akan dikelola menggunakan sistem dan akan disimpan ke dalam database.

\subsection{Metode Perancangan Sistem}

Metode yang digunakan dalam perancangan sistem informasi pengarsipan surat Kantor Desa Sandik ini adalah metode waterfall. Metode waterfall adalah suatu proses pengembangan perangkat lunak berurutan, di mana kemajuan dipandang sebagai terus mengalir ke bawah (seperti air terjun) melewati fase-fase perencanaan, pemodelan, implementasi (konstruksi), dan pengujian. Dalam pengembangannya metode waterfall memiliki beberapa tahapan yang runtut: requirement (analisis kebutuhan), desain sistem (system design), coding \& testing, penerapan program, serta pemeliharaan [14]. 


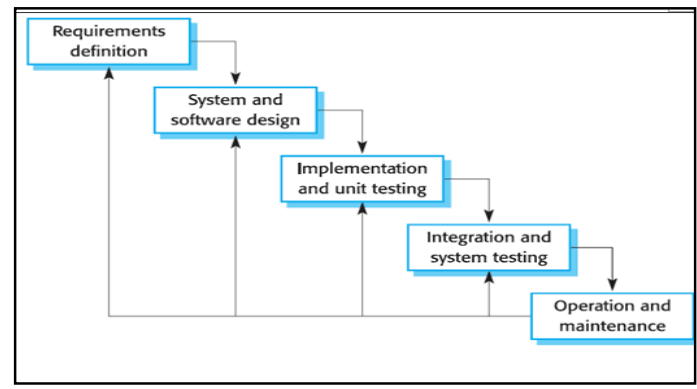

Gambar 4. Metode waterfall

\subsection{Desain Sistem}

Sistem informasi pengarsipan surat pada Kantor Desa Sandik memiliki desain sistem sebagai berikut:

\subsubsection{Use Case Diagram}

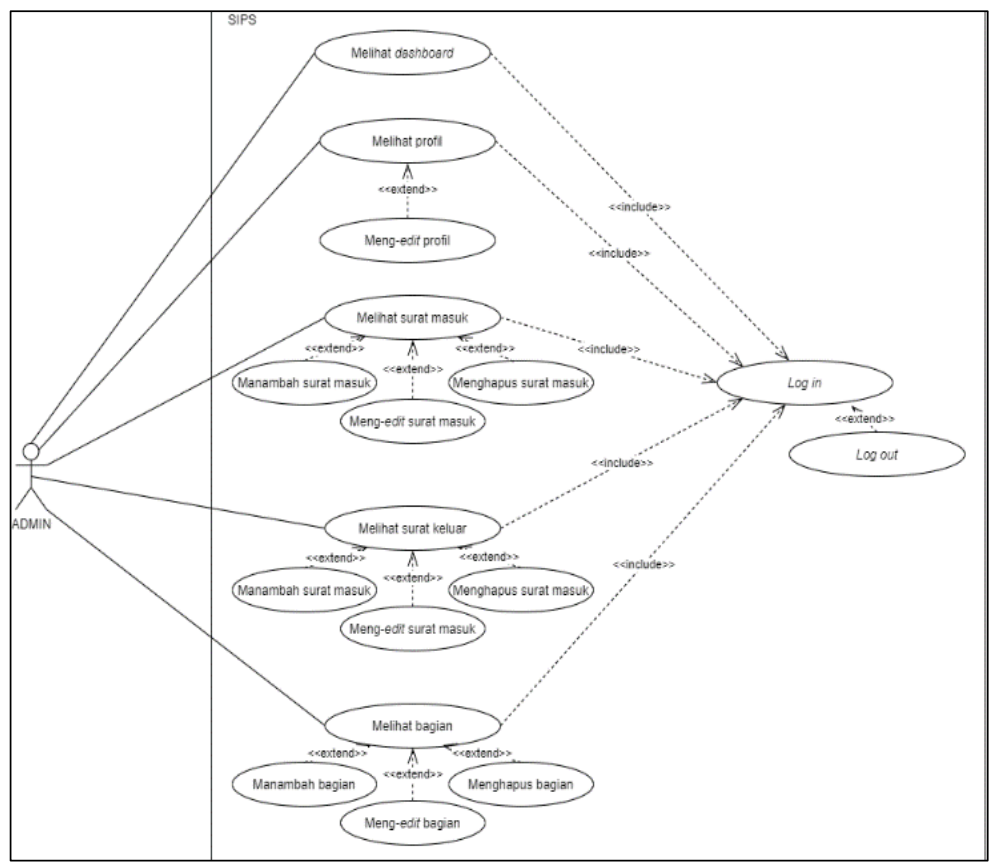

Gambar 5. Use case diagram sistem informasi pengarsipan surat

Gambar 5 merupakan use case diagram dari sistem informasi pengarsipan surat pada Kantor Desa Sandik. Pada use case diagram tersebut, sistem yang dibuat hanya memiliki satu orang aktor, yaitu admin. Pada sistem informasi ini, admin atau yang mengelola sistem dapat melakukan proses-proses sebagai berikut:

1. Melihat dashboard, profil, daftar surat masuk, daftar surat keluar, dan daftar bagian.

2. Melihat detail profil, surat masuk, surat keluar, dan bagian.

3. Menambah surat masuk, surat keluar, dan bagian.

4. Meng-edit profil, surat masuk, surat keluar, dan bagian.

5. Menghapus surat masuk, surat keluar, dan bagian.

\subsubsection{Sequence Diagram}

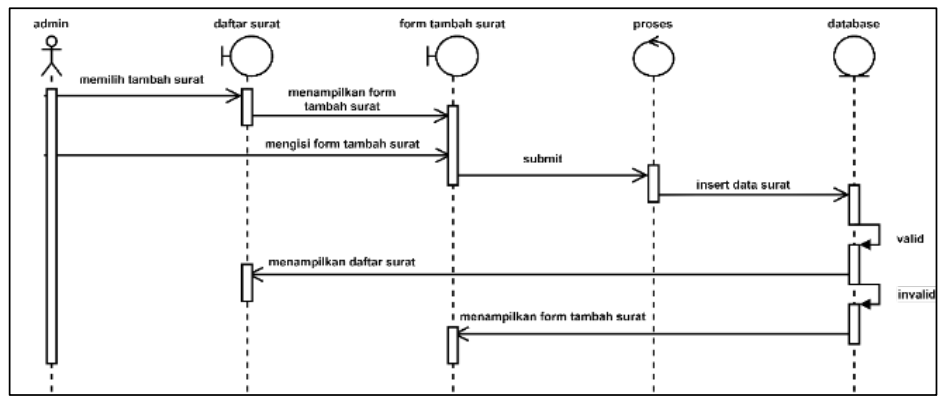

Gambar 6. Sequence diagram tambah surat 
Gambar 6 merupakan sequence diagram dari melakukan tambah surat. Berdasarkan sequence diagram tersebut, saat melakukan tambah surat admin akan memilih tambah surat yang terdapat pada halaman daftar surat baik itu daftar surat masuk maupun keluar, setelah itu form tambah surat akan ditampilkan dan admin akan mengisi form tersebut, lalu admin akan melakukan simpan, setelah itu data surat akan diproses dan dilakukan insert data surat pada database, jika data yang ditambahkan valid maka selanjutnya akan ditampilkan halaman daftar surat, jika tidak maka akan tetap berada pada halaman form tambah surat.

\subsubsection{Activity Diagram}

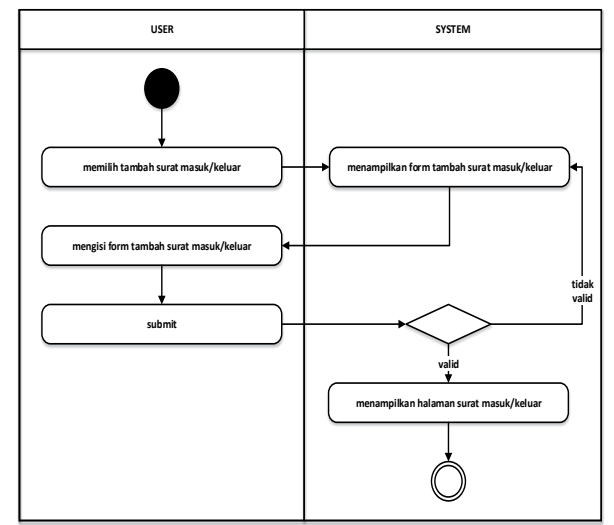

Gambar 7. Activity diagram tambah surat

Gambar 7 merupakan activity diagram dari proses menambah surat. Berdasarkan activity diagram tersebut, user akan memilih menu tambah surat, kemudian sistem kana menampilkan form tambah surat, selanjutnya user akan mengisi form dan melakukan simpan, setelah itu dilakukan pengecekkan, jika data sesuai atau lengkap tanpa kesalahan, maka sistem akan menampilkan halaman daftar surat, sebaliknya jika data tidak sesuai, maka akan tetap berada di halaman form.

\subsubsection{Entity Relationship Diagram (ERD)}

ERD dari sistem informasi pengarsipan surat Kantor Desa Sandik adalah sebagai berikut:

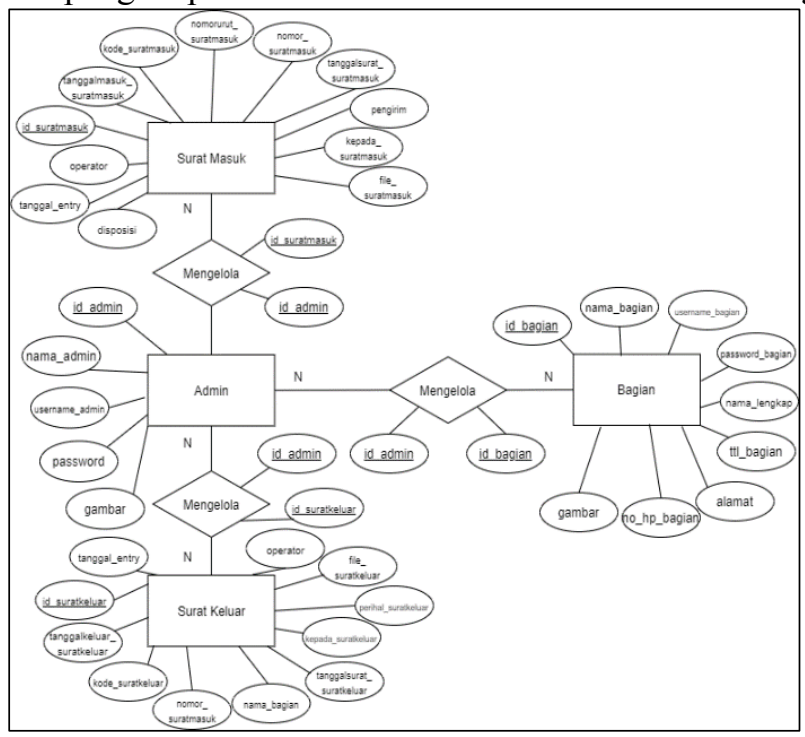

Gambar 8. ERD sistem informasi pengarsipan surat

\subsection{Implementasi Sistem}

Implementasi sistem disesuaikan dengan perancangan pada sub-bab sebelumnya. Berikut adalah implementasi sistem dari sistem informasi pengarsipan surat pada Kantor Desa Sandik:

1. Home 


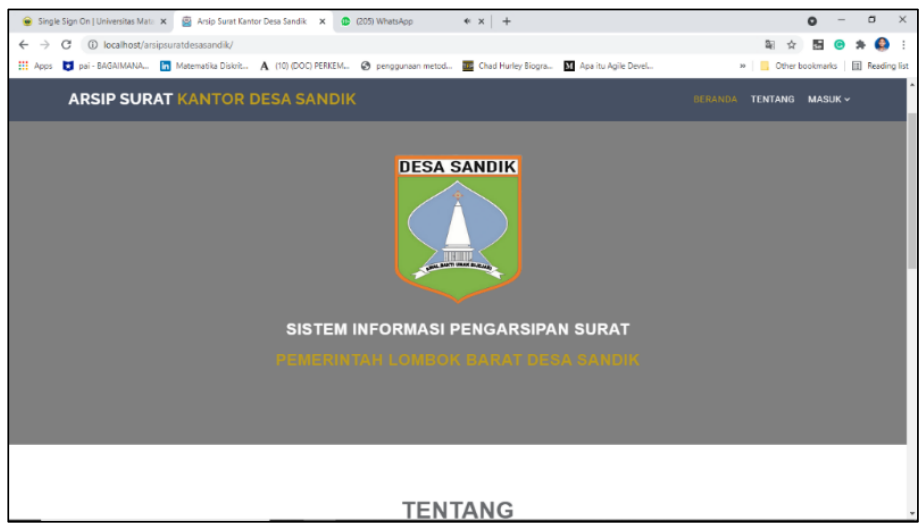

Gambar 9. Implementasi halaman home

Gambar 9 merupakan implementasi dari halaman home dalam sistem informasi pengarsipan surat pada Kantor Desa Sandik. Halaman ini adalah halaman yang pertama kali ditampilkan saat admin membuka sistem informasi pengarsipan surat.

\section{2. $\log \operatorname{In}$}

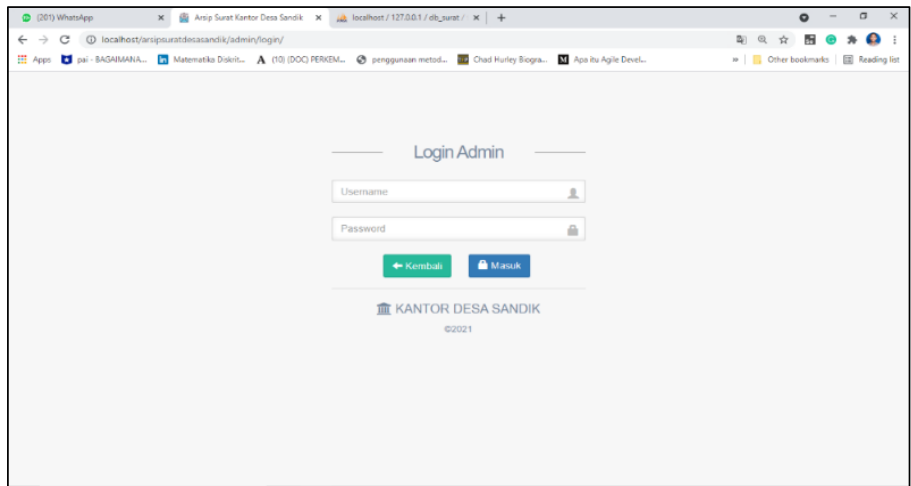

Gambar 10. Implementasi halaman log in

Gambar 10 merupakan implementasi dari halaman $\log$ in dalam sistem informasi pengarsipan surat pada Kantor Desa Sandik. Halaman ini adalah halaman yang pertama kali ditampilkan saat admin telah melakukan $\log$ in yang nantinya admin disini dapat melakukan pengelolaan pengarsipan surat.

\section{Dashboard}

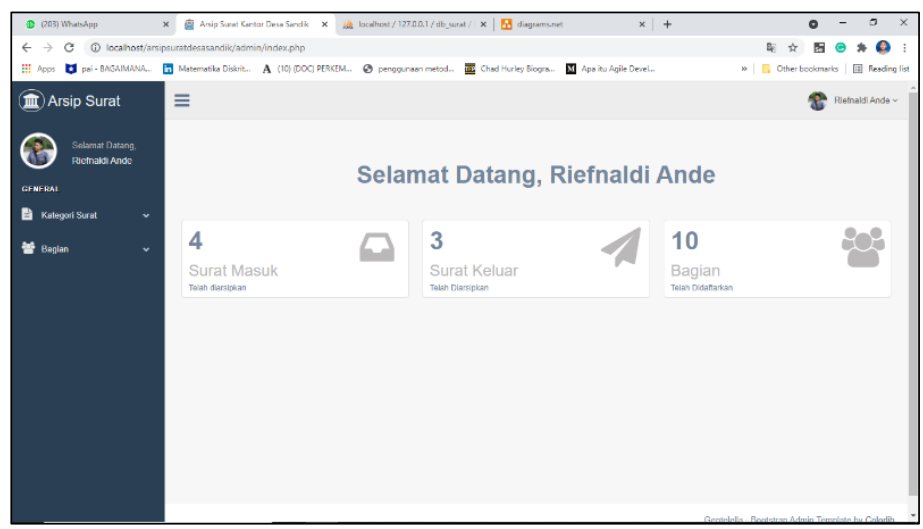

Gambar 11. Implementasi halaman dashboard

Gambar 11 merupakan implementasi dari halaman dashboard dalam sistem informasi pengarsipan surat pada Kantor Desa Sandik. Halaman ini adalah halaman yang pertama kali ditampilkan setelah admin berhasil melakukan $\log$ in.

4. Profil 


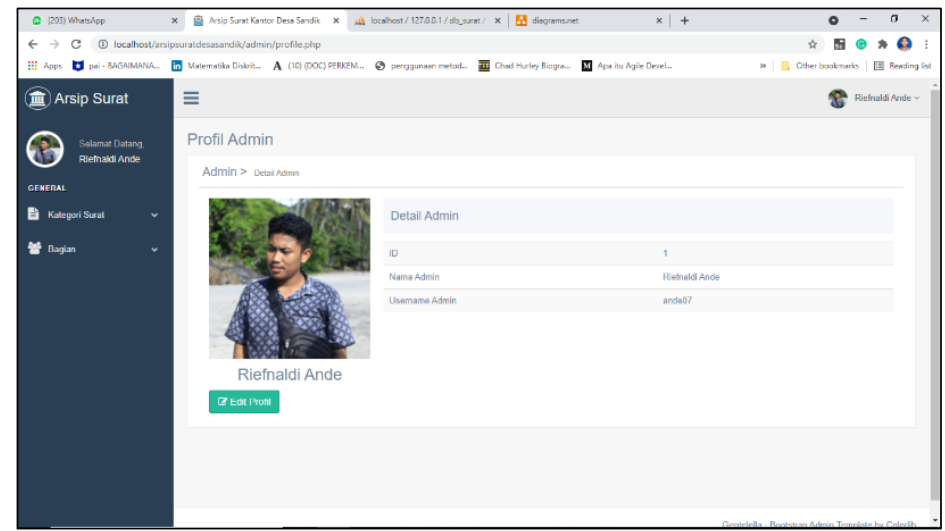

Gambar 12. Implementasi halaman profil

Gambar 12 merupakan implementasi dari halaman profil dalam sistem informasi pengarsipan surat pada Kantor Desa Sandik. Halaman ini adalah halaman yang digunakan admin untuk melihat profil.

\section{Edit Profil}

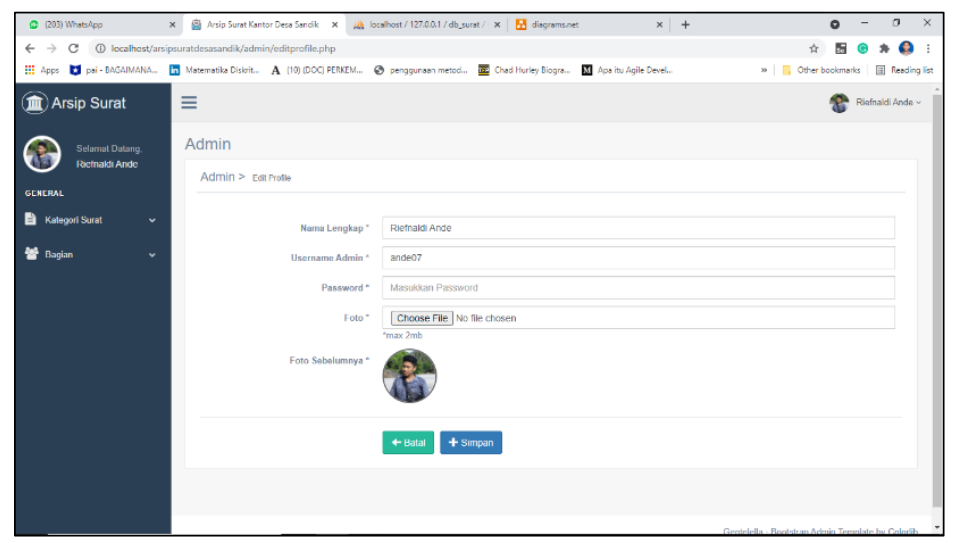

Gambar 13. Implementasi halaman edit profil

Gambar 13 merupakan implementasi dari halaman edit profil dalam sistem informasi pengarsipan surat pada Kantor Desa Sandik. Halaman ini adalah halaman yang digunakan admin untuk mengubah data profilnya, seperti nama lengkap, username, password, dan foto.

6. Daftar Surat Masuk

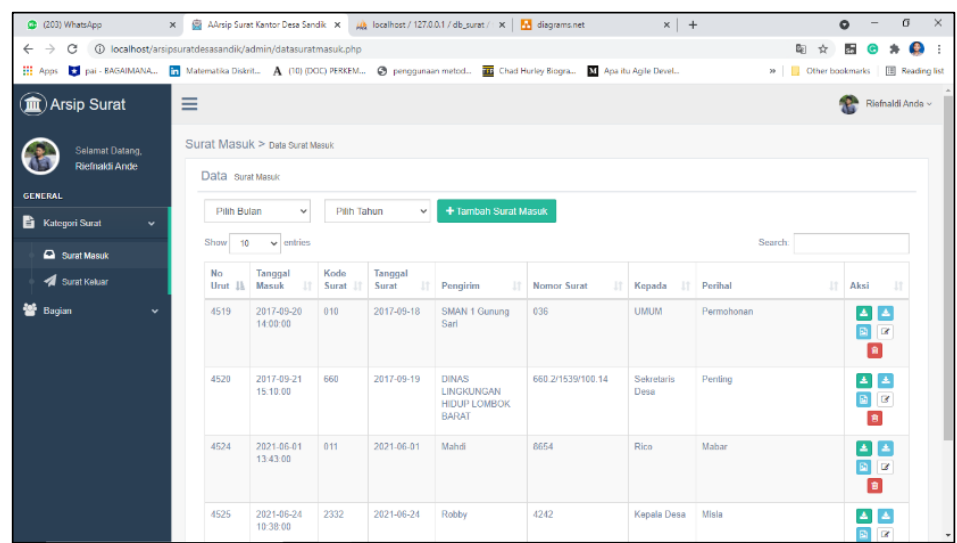

Gambar 14. Implementasi halaman daftar surat masuk

Gambar 14 merupakan implementasi dari halaman daftar surat masuk dalam sistem informasi pengarsipan surat pada Kantor Desa Sandik. Halaman ini adalah halaman yang digunakan admin untuk melihat daftar data surat masuk, serta terdapat beberapa tombol yang digunakan untuk melakukan tambah surat, edit surat, unduh file surat, lihat detail surat, dan hapus surat. 
7. Tambah Surat Masuk

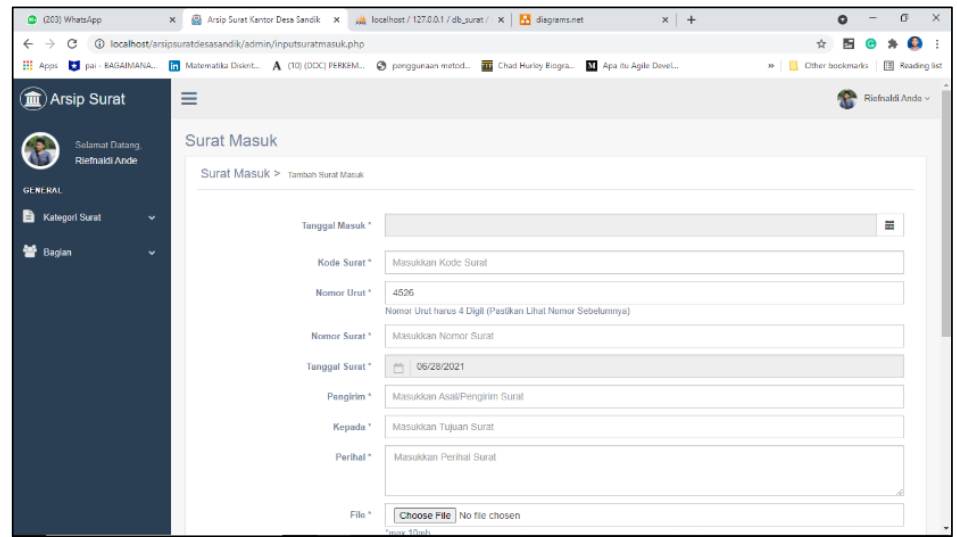

Gambar 15. Implementasi halaman tambah surat masuk

Gambar 15 merupakan implementasi dari halaman tambah surat masuk dalam sistem informasi pengarsipan surat pada Kantor Desa Sandik. Halaman ini akan ditampilkan ketika admin memilih tombol tambah surat masuk pada daftar surat masuk. Pada halaman ini admin dapat menambahkan data surat masuk, seperti tanggal masuk, kode surat, nomor urut, nomor surat, tanggal surat, pengirim, kepada, perihal, dan file.

\section{Edit Surat Masuk}

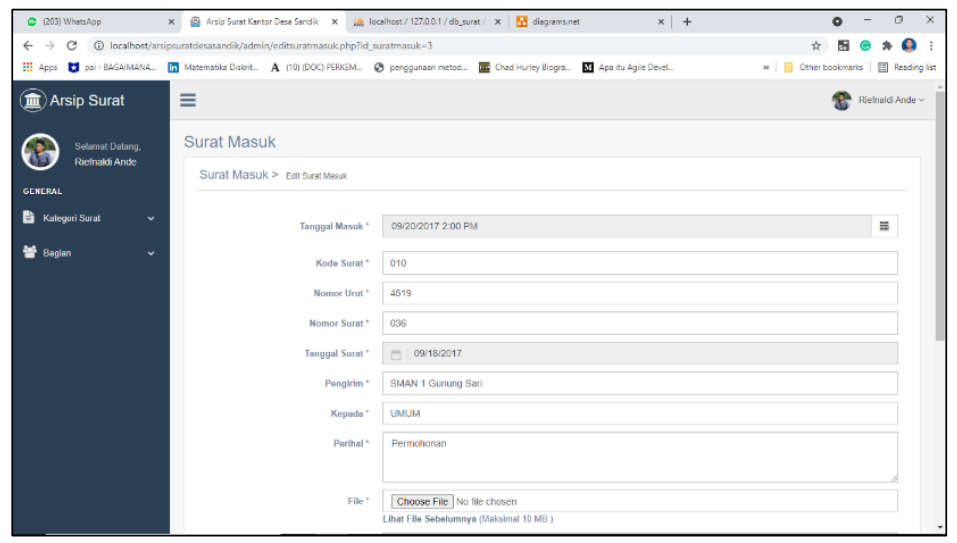

Gambar 16. Implementasi halaman edit surat masuk

Gambar 16 merupakan implementasi dari halaman edit surat masuk dalam sistem informasi pengarsipan surat pada Kantor Desa Sandik. Halaman ini akan ditampilkan ketika admin memilih tombol edit surat pada daftar surat masuk. Pada halaman ini admin dapat mengubah data surat masuk, seperti tanggal masuk, kode surat, nomor urut, nomor surat, tanggal surat, pengirim, kepada, perihal, dan file.

\section{Daftar Surat Keluar}

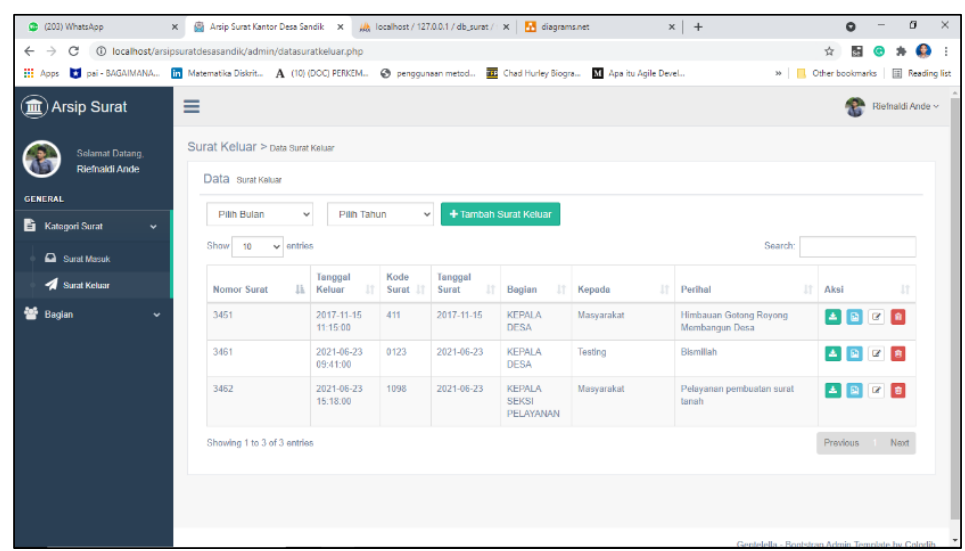

Gambar 17. Implementasi halaman daftar surat keluar 
Gambar 17 merupakan implementasi dari halaman daftar surat keluar dalam sistem informasi pengarsipan surat pada Kantor Desa Sandik. Halaman ini adalah halaman yang digunakan admin untuk melihat daftar data surat keluar, serta terdapat beberapa tombol yang digunakan untuk melakukan tambah surat, edit surat, unduh file surat, lihat detail surat, dan hapus surat.

10. Tambah Surat Keluar

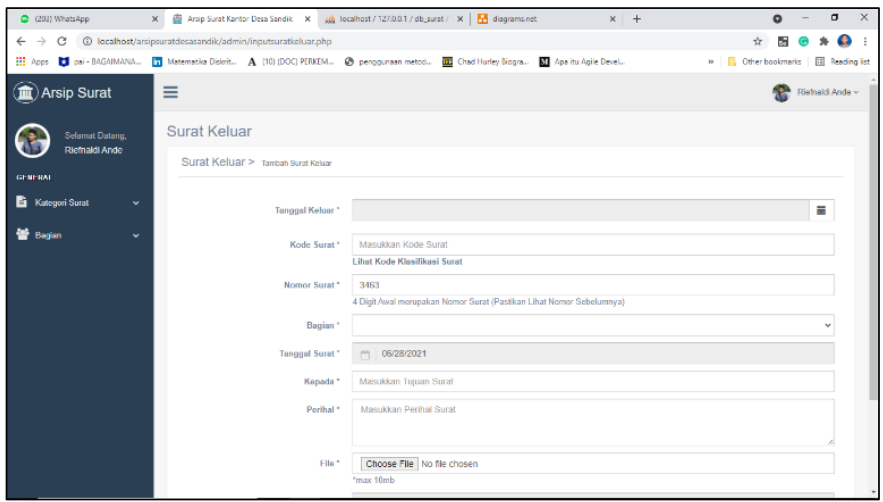

Gambar 18. Implementasi halaman tambah surat keluar

Gambar 18 merupakan implementasi dari halaman tambah surat keluar dalam sistem informasi pengarsipan surat pada Kantor Desa Sandik. Halaman ini akan ditampilkan ketika admin memilih tombol tambah surat keluar pada daftar surat keluar. Pada halaman ini admin dapat menambahkan data surat keluar, seperti tanggal keluar, kode surat, nomor surat, bagian, tanggal surat, kepada, perihal, dan file.

\section{Daftar Bagian}

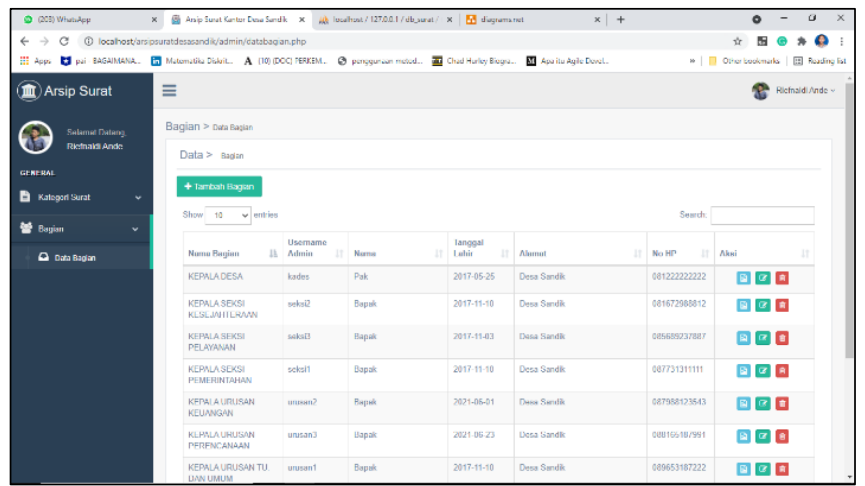

Gambar 19. Implementasi halaman daftar bagian

Gambar 19 merupakan implementasi dari halaman daftar bagian dalam sistem informasi pengarsipan surat pada Kantor Desa Sandik. Halaman ini akan ditampilkan ketika admin memilih menu data bagian pada menu bagian. Halaman ini berisikan daftar-daftar bagian yang ada pada kantor Desa Sandik, serta terdapat beberapa tombol yang digunakan oleh admin untuk melakukan tambah bagian, edit bagian, lihat detail bagian, dan hapus bagian.

\section{HaSil DaN PEMbahasan}

Testing sistem informasi company profile pada Kantor Desa Sandik menggunakan metode user acceptance testing. Metode user acceptance testing menggunakan black box testing dan kuesioner dalam pengujiannya. Berikut hasil dari testing yang telah dilakukan:

\subsection{Black Box Testing}

Metode pengujian black box merupakan metode pengujian yang menguji fungsi-fungsi di dalam sistem untuk menentukan apakah fungsi-fungsi tersebut sudah berjalan sesuai harapan atau tidak. Berdasarkan pengujian black box yang telah dilakukan pada seluruh fitur yang terdapat dalam sistem, fitur-fitur tersebut diuji dengan berbagai data masukan. Sehingga didapat kesimpulan bahwa fitur-fitur yang ada pada sistem informasi pengarsipan surat pada Kantor Desa Sandik telah berjalan dengan baik.

\subsection{Kuisioner}

Penulis menanyakan kepada kepala desa, sekretaris desa, dan pegawai tata usaha selaku operator mengenai sistem yang telah dibuat, apakah sistem sesuai atau tidak dengan kebutuhan. Jika belum sesuai, maka akan kembali 
ke perancangan sistem hingga sesuai dengan keinginan dan kebutuhan pengguna. Untuk mengetahui hal tersebut, makadilakukan evaluasi melalui kuesioner. Parameter pengujian yang digunakan pada metode ini adalah:

a. Apakah sistem yang dibuat sudah sesuai dengan kebutuhan pada Kantor Desa Sandik?

b. Apakah sistem yang dibuat dapat mempermudah pegawai dalam mengelola dan mengarsipkan surat?

c. Apakah sistem yang digunakan mudah digunakan?

d. Apakah sistem menghasilkan informasi yang detail?

e. Dalam hal tata letak (design), apakah sistem mudah untuk dibaca dan dipahami?

f. Apakah sistem sudah bekerja sesuai dengan kegunaan dan fungsinya?

Responden akan diberikan pilihan jawaban dari pertanyaan-pertanyaan tersebut, sebagai berikut:

a. Ya

b. Tidak

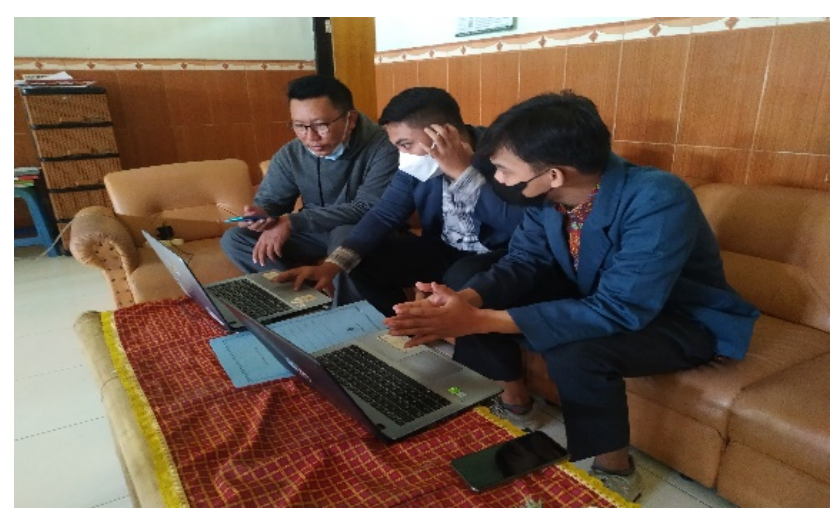

Gambar 20. Presentasi pengujian sistem

Hasil rekapitulasi jawaban responden dihitung dari jawaban berdaarkan pengisian kuesioner dari masingmasing pertanyaan. Berikut merupakan grafik persentase jawaban rata-rata hasil pengujian dari 5 responden:

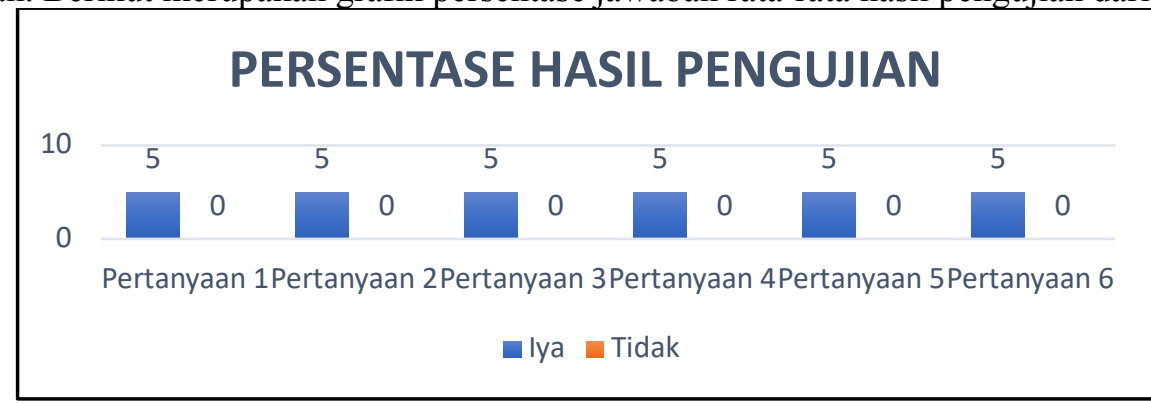

Gambar 21. Persentase hasil pengujian

Pada gambar 21 merupakan hasil dari persentase pengujian dari kuesioner yang diberikan mendapatkan nilai untuk pertanyaan 1 nilai Iya diberikan oleh 5 orang responden, untuk pertanyaan 2 nilai Iya diberikan oleh 5 orang responden, untuk pertanyaan 3 nilai Iya diberikan oleh 5 orang responden, untuk pertanyaan 4 nilai Iya diberikan oleh 5 orang responden, untuk pertanyaan 5 nilai Iya diberikan oleh 5 orang responden dan untuk pertanyaan 6 nilai Iya diberikan oleh 5 orang responden. Sehingga dapat disimpulkan bahwa dari responden setuju dengan sistem yang telah dibangun.

\section{KESIMPULAN DAN SARAN}

\subsection{Kesimpulan}

Berdasarkan hasil pengabdian masyarakat di Kantor Desa Sandik didapatkan kesimpulan sebagai berikut:

1. Sistem informasi pengarsipan surat yang dibuat dapat digunakan untuk melakukan pendataan, pengelolan, pengarsipan, serta mencetak surat masuk dan surat keluar di Kantor Desa Sandik.

2. Fitur-fitur yang terdapat pada sistem informasi pengarsipan surat ini, seperti data surat baik surat masuk maupun keluar, dan profil masing-masing memiliki fungsinya sendiri yang dapat berjalan dengan baik dengan kepuasan $100 \%$ dari 5 pengguna.

3. Sistem informasi pengarsipan surat hanya memiliki satu pengguna, yaitu admin yang seluruh proses yang terdapat pada sistem. 


\subsection{Saran}

Berdasarkan sistem informasi pengarsipan surat yang telah dibuat, penulis menyarankan beberapa hal yaitu:

1. Melakukan perbaikan pada tampilan serta menambahkan fitur-fitur baru untuk dapat lebih menunjang kinerja dari sistem dan memudahkan operator dalam mengelola surat.

2. Perlu diadakannya penambahan pada fitur kemananya agar sistem dapat lebih aman semisal dengan menggunakan framework seperti codeigniter sehingga setiap halamannya tidak bisa diakses langsung melalui link.

3. Sistem informasi pengarsipan surat yang dibuat perlu di online kan agar admin dapat membuka dan mengakses darimana saja.

\section{UCAPAN TERIMA KASIH}

Ucapan terima kasih kepada instansi tempat saya melakukan kegiatan ini yaitu Kantor Desa Sandik khususnya kepada bapak Kepala Desa yang telah memberikan saya kesempatan dalam melakukan kegiatan pengabdian masyarakat ini. Dan juga saya ucapkan terima kasih kepada dosen pembimbing saya yaitu bapak Arik Aranta, S.Kom., M.Kom., yang telah membimbing saya dalam menyelesaikan kegiatan pengabdian ini. Serta kepada keluarga dan teman-teman yang membantu penulis dalam melaksanakan pengabdian ini.

\section{DAFTAR PUSTAKa}

[1] Williams, Brian K., Stacey C. Sawyer, Using Information Technology (Terjemahan Indonesia), Yogyakarta: Andi Offset, 2007.

[2] Amri, Arni Muarifah, Kurnia Cahya Lestari, Sistem Informasi Akuntasi (Beserta Contoh Penerapan Aplikasi SIA Sederhana dalam UMKM), Yogyakarta: Penerbit Deepublish, 2020.

[3] Taufiq, Rohmat, Sistem Informasi Manajemen, Yogyakarta: Graha Ilmu, 2013.

[4] Hartono, Jogiyanto, Analisis dan Desain Sistem Informasi, Yogyakarta: Andi Offset, 2005.

[5] Sutabri, Tata, Analisis Sistem Informasi, Yogyakarta, 2012.

[6] Prijambodo, Out of The Box: Koperasi Tantangan Perubahan Kini dan Masa Depan. Yogyakarta: Phoenix Publisher, 2018.

[7] Anhar, Panduan Menguasai PHP dan MySQL Secara Otodidak, Jakarta: Mediakita, 2010.

[8] Hartono, Hamzah, Pengertian Website Dan Fungsinya, Ilmu Teknologi Informasi, pp. 2-7, 2014.

[9] Haviluddin, "Memahami Penggunaan UML (Unified Modelling Language)," Jurnal Informatika Mulawarman, vol. 6, No. 1, Februari 2011, pp. 1-15.

[10] Dharwiyanti, Sri, Pengantar Unfied Modeling Language, Jurnal Kuliah Umum IlmuKomputer.com, 2003.

[11] Peranginangin, Teknik Cepat Menguasai PHP MySQL dalam Waktu yang Sangat Singkat, Jakarta: Kuncikom, 2016.

[12] Alatas, Husein, Responsive Web Design dengan PHP dan Bootstrap, Yogyakarta: Lokomedia, 2013.

[13] Hidayatullah, Priyanto, Pemrograman Web, Bandung: Informatika Bandung, 2015.

[14] Chrisantus Tristanto, "Penggunaan Metode Waterfall untuk Pengembangan Sistem Monitoring dan Evaluasi Pembangunan Pedesaan,” Jurnal Teknologi Informasi ESIT, vol. XII, No. 1, April 2018, pp. 8 - 22.

[15] Sommervile, I, Software Engineering 9th Edition, Addison - Wesley, 2011.

[16] Sumiati, Sri Endang Anjarwani, dan Moh. Ali Albar, "Rancang Bangun Sistem Informasi Pengelolaan Surat dan Kearsipan pada Sekretariat Daerah Provinsi NTB Berbasis Web," J-COSINE, vol. 2, no. 1, hal. 7 - 16, Juni 2018. 